spatial reconstruction (nasal cavity, vomeronasal organ, olfactory nerves, olfactory bulbi) of European green lizard's embryo at the $34^{\text {th }}$ stage of development is described. Construction of three-dimensional model in the program Amira 5,0 . is done on the basis of photos of serial histological sections. The work in the program consists of preparing of microphotos, levelling of structures under investigation, picking out the contours and creation of three-dimensional model. Doing spatial reconstruction with the help of Amira doesn't demand great time consumption and special training and is suited for all biological objects. The spatial model of lizard's embryo which was created exactly reflects all morphological particularities of olfactory elements. This model is easy to use, it allows to see and to describe all morphological structures.

Key words: embryo, spatial reconstruction, olfactory epithelium, vomeronasal organ.

Стаття надійшла до редколегії 05.10.2015 p.

УДК 593.16(477.41/42)

\title{
Світлана Шевчук,
} Людмила Васільєва

\section{Залежність чисельності гетеротрофних джгутикових центральної частини Українського Полісся від абіотичних факторів водного середовища}

Досліджено залежність чисельності гетеротрофних джгутикових центральної частини Українського Полісся від активної реакції водного середовища, умісту розчинених у воді кисню та органічних речовин. Установлено, що чисельність P. nitrophilus залежить від $\mathrm{pH}$ і розчинених у воді органічних речовин, A. tachyploon, B. globosus, G. truncata, P. apiculatus, $R$. nasuta - від розчиненого у воді кисню, а A. sigmoides, B. saltans, P. simplex - від розчинених у воді органічних речовин.

Ключові слова: гетеротрофні джгутикові, Українське Полісся, абіотичні фактори водного середовища.

Постановка наукової проблеми та її значення. Гетеротрофні джгутикові - найменш вивчений компонент водних біоценозів, хоча відома їх значна роль у функціонуванні останніх [7]. Ці протисти широко представлені серед усіх екологічних груп гідробіонтів і трапляються майже у всіх біотопах [3; 8]. Однак до сьогодні залишаються недостатньо вивченими питання екології гетеротрофних джгутикових, особливо аутекології.

Аналіз досліджень цієї проблеми. Більшість гетеротрофних джгутикових еврибіонтні, вони здатні існувати в широкому діапазоні екологічних факторів, таких як рН, солоність, температура та концентрація кисню, хоча для різних видів існують свої оптимуми [3]. Що стосується температури, то для кінетопластид, церкомонадид, хризомонади й евгленід оптимальна температура перебуває в межах від 15-26 ${ }^{\circ} \mathrm{C}$, тому в підлідний період їх чисельність зазвичай невисока [4]. Ця група протистів надає перевагу водоймам зі значеннями активної реакції водного середовища, що близькі до нейтральних [5]. Однак експериментальні дані та спостереження в природі вказали, що при значеннях $\mathrm{pH}$ у межах 3,4-4,0 успішно розвиваються комірцеві джгутикові, деякі кінетопластиди, хризофітові й частково евгленові [1]. Щодо розчиненого у воді кисню менш вимогливі бентосні та перифітонні джгутикові, а для дипломонадид кисень узагалі згубний. Достатньої кількості кисню потребують планктонні форми. Дані досліджень із культивування гетеротрофних джгутикових на середовищах різного складу засвідчують позитивний вплив розчинених органічних речовин на їх розвиток [3; 6]. Отже, накопичено дані щодо впливу абіотичних факторів на загальну чисельність гетеротрофних джгутикових, а не конкретних видів.

Мета роботи - 3'ясувати залежність чисельності гетеротрофних джгутикових центральної частини Українського Полісся від активної реакції водного середовища, умісту розчинених у воді кисню й органічних речовин.

(С Шевчук С., Васільєва Л., 2015 
Матеріали та методи дослідження. Проби відбирали методом простого зачерпування води в різних типах водойм Житомирського та Київського Полісся. Транспортували в скляному або поліетиленовому посуді. Зразу після транспортування проводили ідентифікацію видів і підрахунок їх кількості. Неконцентровані проби об'ємом 5 мл розливали в чашки Петрі діаметром 6 см по три повторності з кожного місця збору матеріалу. Проби вивчали під світловим мікроскопом МИКМЕД 3 об' єктивом водної імерсії $\times 70$ і окуляром $\times 15$. У кожній чашці розглядали 15 полів зору. Розрахунок чисельності джгутикових в 1 мл визначали за формулою:

$$
N=n \times S / V \times s,
$$

де $N$ - кількість джгутикових в 1 мл; $n$ - кількість організмів у просторових полях зору; $S$ - площа чашки Петрі; $s$ - площа просторових полів зору; $V$ - використаний об’ $є$ м проби.

Дані накопичували в таблицях статистичного пакета STATISTICA 6.0. Вплив абіотичних факторів на чисельність гетеротрофних джгутикових визначали за допомогою однофакторного дисперсійного аналізу. Вимірювання рН здійснювали електрометрично.

Оксигенізацію води визначали за кількістю розчиненого кисню у воді, що вимірюється в мг/л. Окиснювальність води установлювали перманганатним методом.

Виклад основного матеріалу й обгрунтування отриманих результатів дослідження. У результаті наших досліджень установлено достовірний зв'язок ( $\mathrm{p}=0,04)$ (рис. 1) між чисельністю Parabodo nitrophilus Skuja, 1948 та активною реакцією водного середовища $(\mathrm{pH})$.

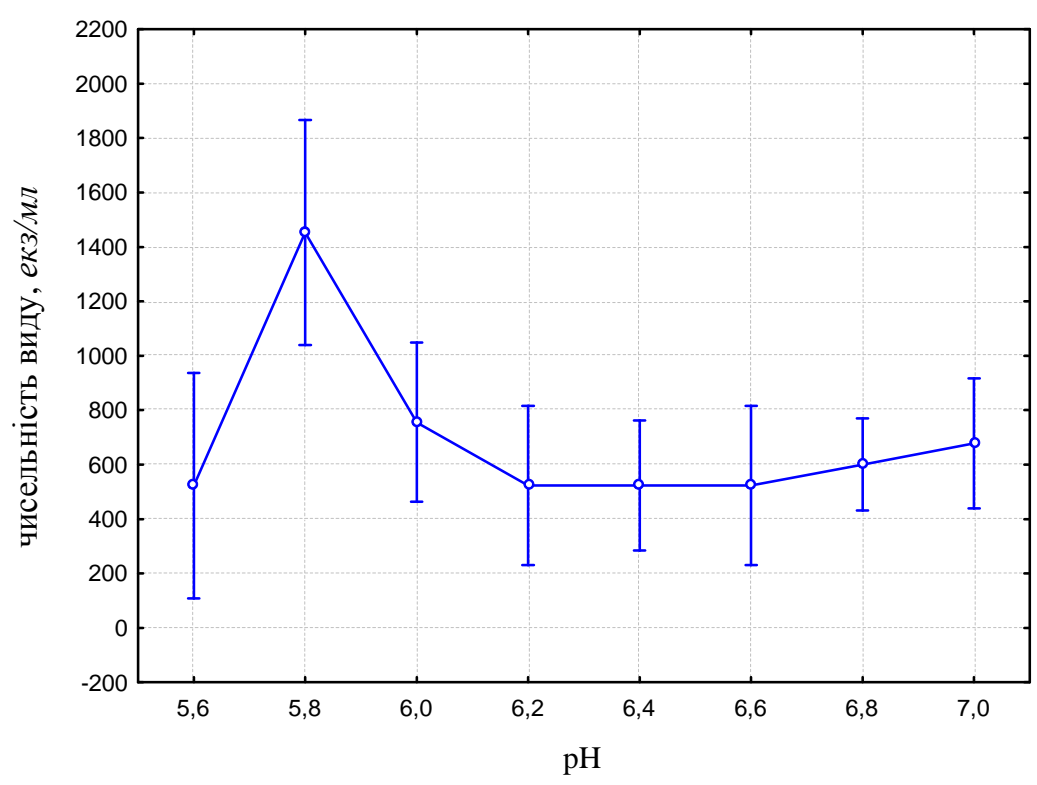

Рис. 1. Залежність між чисельністю P. nitrophilus та $\mathrm{pH}$ (результати однофакторного дисперсійного аналізу)

Максимальну чисельність (989-1453 екз/мл) вищевказаного виду зафіксовано при значеннях $\mathrm{pH}$ у діапазоні 5,6-6,3. Можна припустити, що в цьому діапазоні рН перебуває оптимум для цього виду.

Крім того, у результаті нашого дослідження видів Allantion tachyploon Sandon, 1924 (рис. 2), Bodo globosus Stein, 1878 (рис. 3), Goniomonas truncata (Fresenius) Stein, 1887 (рис. 4.), Phyllomitus apiculatus Skuja, 1948 (рис. 5), Rhynchomonas nasuta (Stokes, 1888) Klebs, 1893 (рис. 6) установлено наявність достовірного зв' язку між їх чисельністю й умістом розчиненого у воді кисню.

Найбільшу чисельність (58-523 екз/мл) виду A. tachyploon простежено при концентрації кисню у воді 2,6-6,9 мг/л, яка є оптимальною для виду ( $\mathrm{p}=0,04)$. 


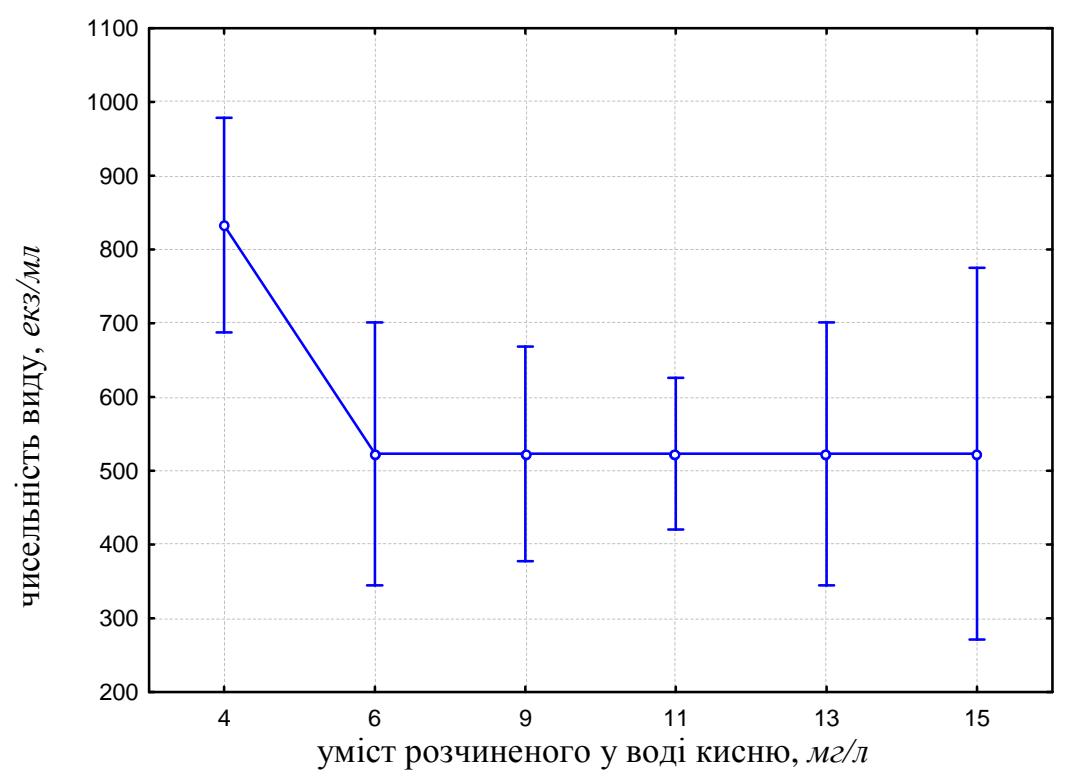

Рис. 2. Залежність чисельності A. tachyploon від умісту розчиненого у воді кисню (результати однофакторного дисперсійного аналізу)

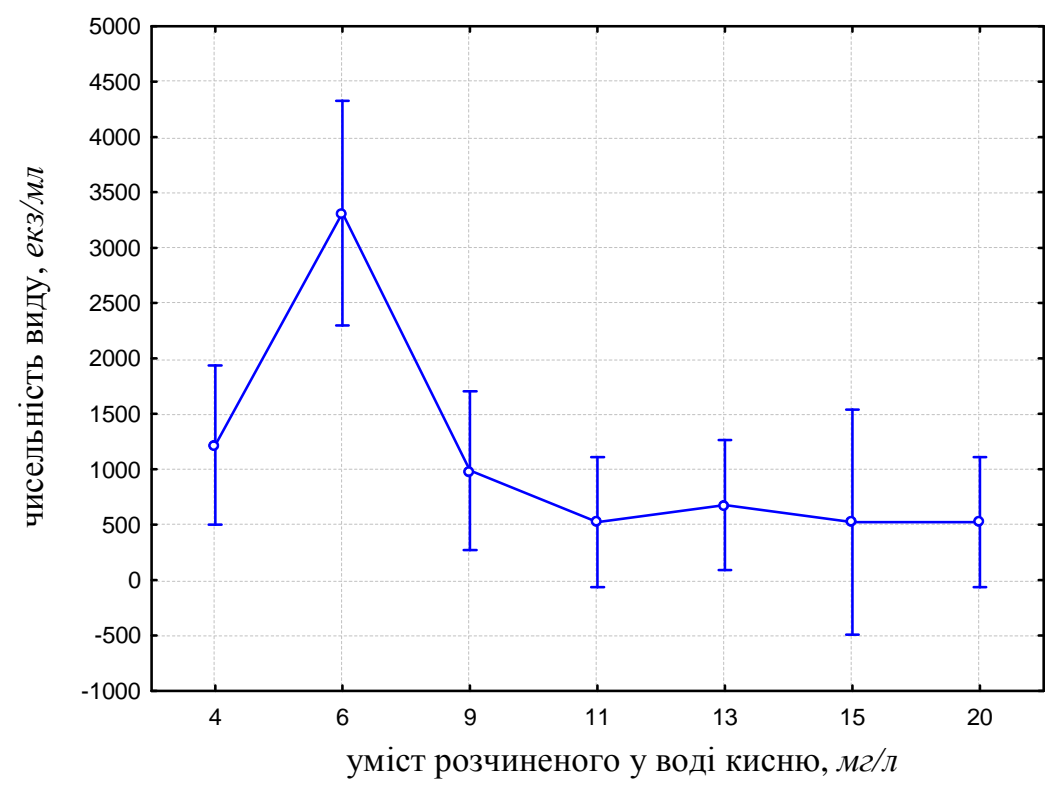

Рис. 3. Залежність чисельності B. globosиs від умісту розчиненого у воді кисню (результати однофакторного дисперсійного аналізу)

Для виду B. globosus зафіксовано оптимальні значення концентрацій розчиненого у воді кисню, що коливаються в межах 2,6-9,1 мг/л. При цих значеннях концентрацій простежено значне підвищення кількості цього виду до 2844-3313 екз/мл (p=0,01), при тому, що при інших концентраціях кисню цей вид у пробах трапляється в кількості 58-523 екз/мл.

Для виду G. truncata 3 високим ступенем достовірності $(\mathrm{p}=0,001)$ зафіксовано залежність між чисельністю та вмістом кисню у воді. При чому якщо для двох попередньо розглянутих видів це були низькі значення концентрації кисню у воді, то для G. truncata максимальну чисельність (42434708 екз/мл) цього виду простежували при 17,9-24,5 мг/л. Такі значення розчиненого кисню можуть траплятися при взаємодії двох факторів: інтенсивного фотосинтезу водоростей та вищих водних рослин у теплий період, а також надходження кисню у воду з повітря. 


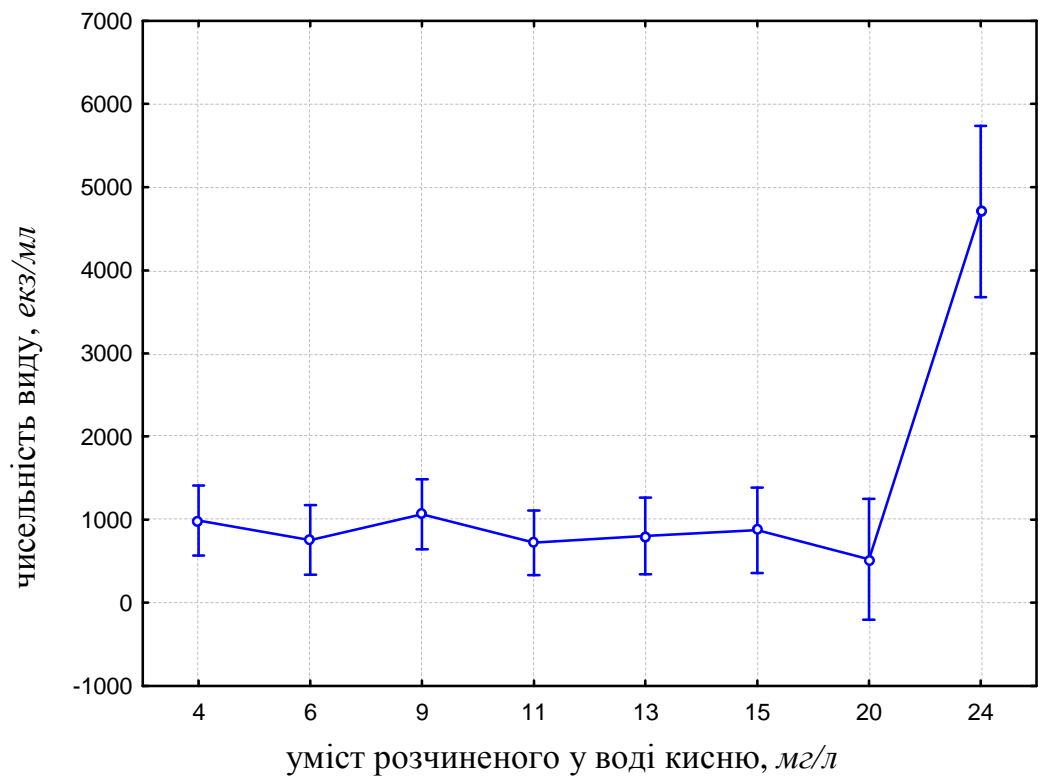

Рис. 4. Залежність чисельності G. truncata від умісту розчиненого у воді кисню (результати однофакторного дисперсійного аналізу)

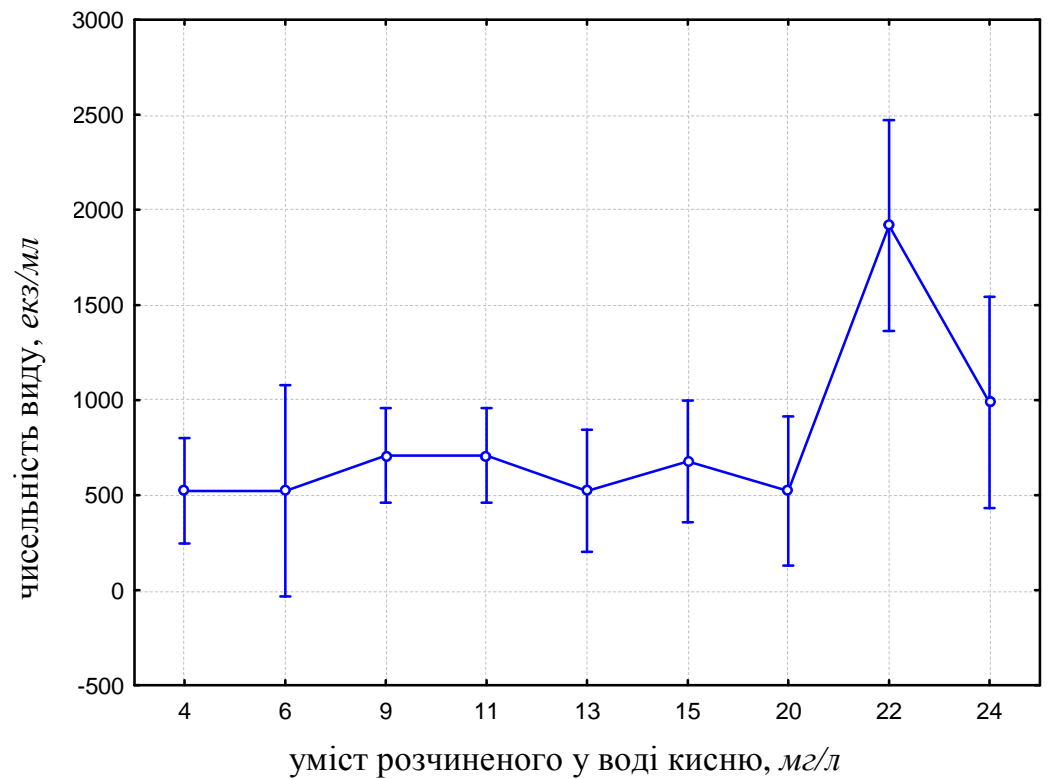

Рис. 5. Залежність чисельності Р. apiculatus від умісту розчиненого у воді кисню (результати однофакторного дисперсійного аналізу)

Для виду P. apiculatus нами зареєстровано оптимальний діапазон концентрацій кисню 17,9-24,5 мг/л, при якому чисельність цього виду сягає 1454-1918 екз/мл (р=0,02), тоді як при нижчих показниках чисельність P. apiculatus досягала лише 523 екз/мл. 


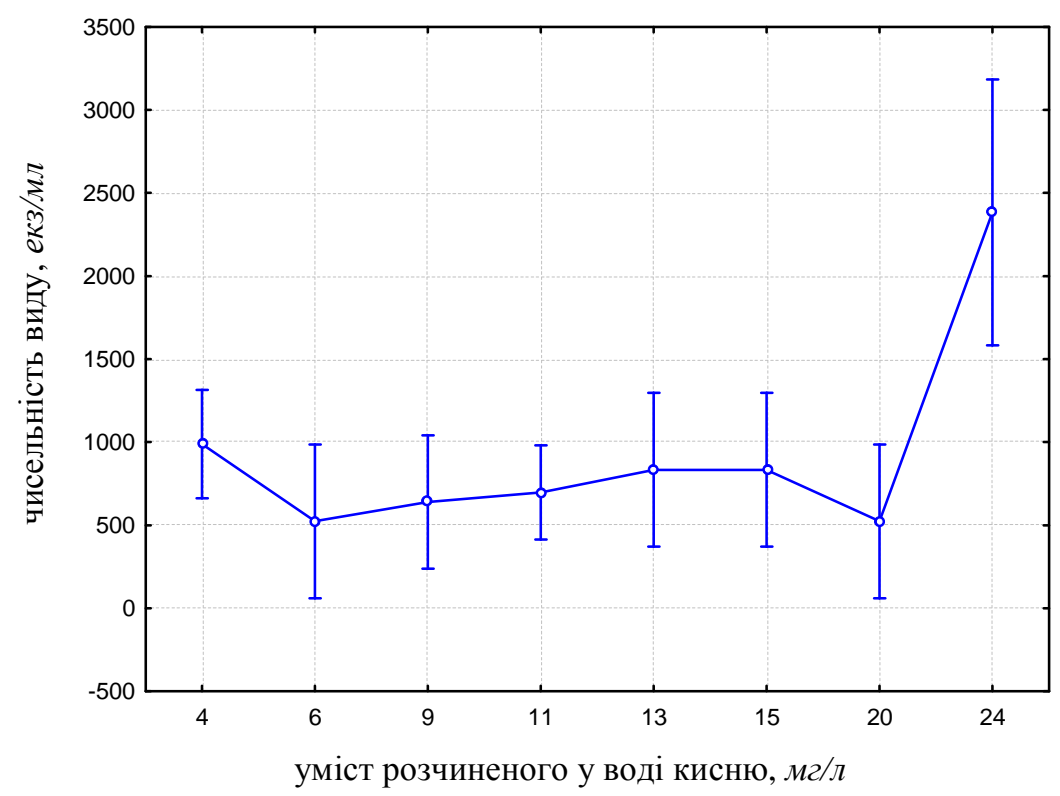

Рис. 6. Залежність чисельності R. палита від умісту розчиненого у воді кисню (результати однофакторного дисперсійного аналізу)

Для виду $R$. nasuta нами зафіксовано найвищу чисельність (1919-2383 екз/мл) також при високих концентраціях кисню у воді 22,4-24,5 мг/л (р=0,02).

Установлено, що для видів Ancyromonas sigmoides Kent, 1880 (рис. 7), Bodo saltans Ehrenberg, 1838 (рис. 8), P. nitrophilus (рис. 9) і Protaspis simplex Vǿrs, 1992 (рис. 10) існує достовірний зв'язок між чисельністю та вмістом розчинених органічних речовин.

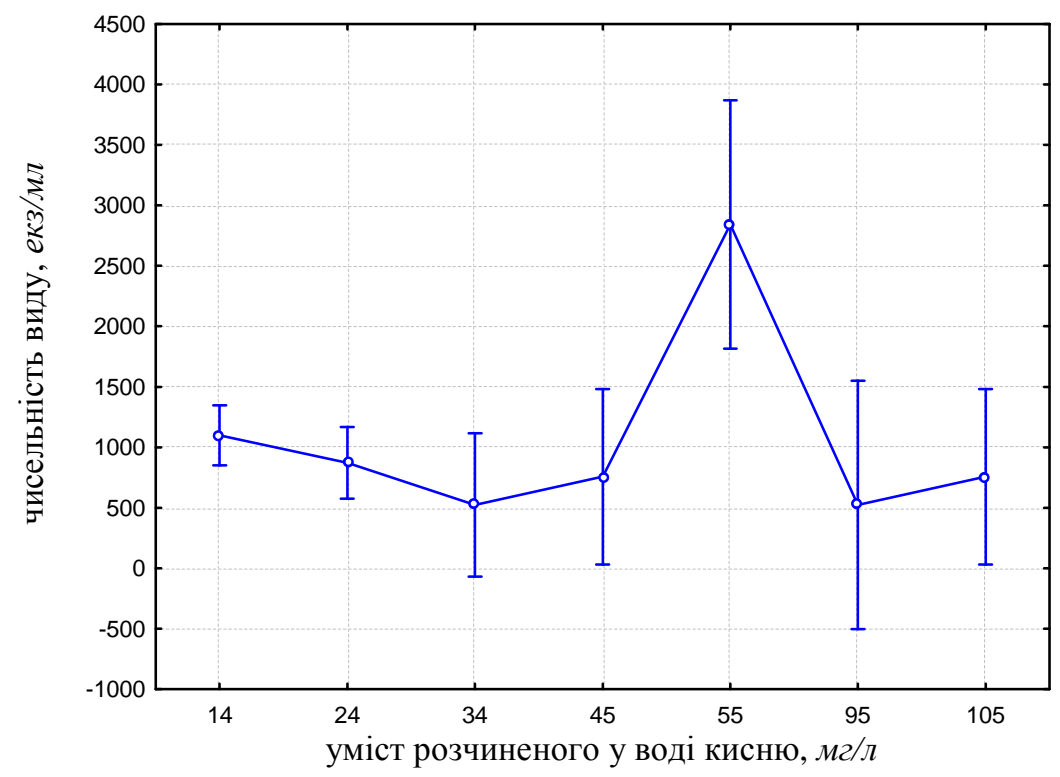

Рис. 7. Залежність чисельності A. sigmoides від умісту розчинених у воді органічних речовин (результати однофакторного дисперсійного аналізу)

Для виду A. sigmoides простежують найвищі показники чисельності (2384-3313 екз/мл) при концентрації розчинених речовин 45,1-55,1 мг $\mathrm{O}_{2} / л$ ( $\left.\mathrm{p}=0,01\right)$, що є оптимальними для виду. 


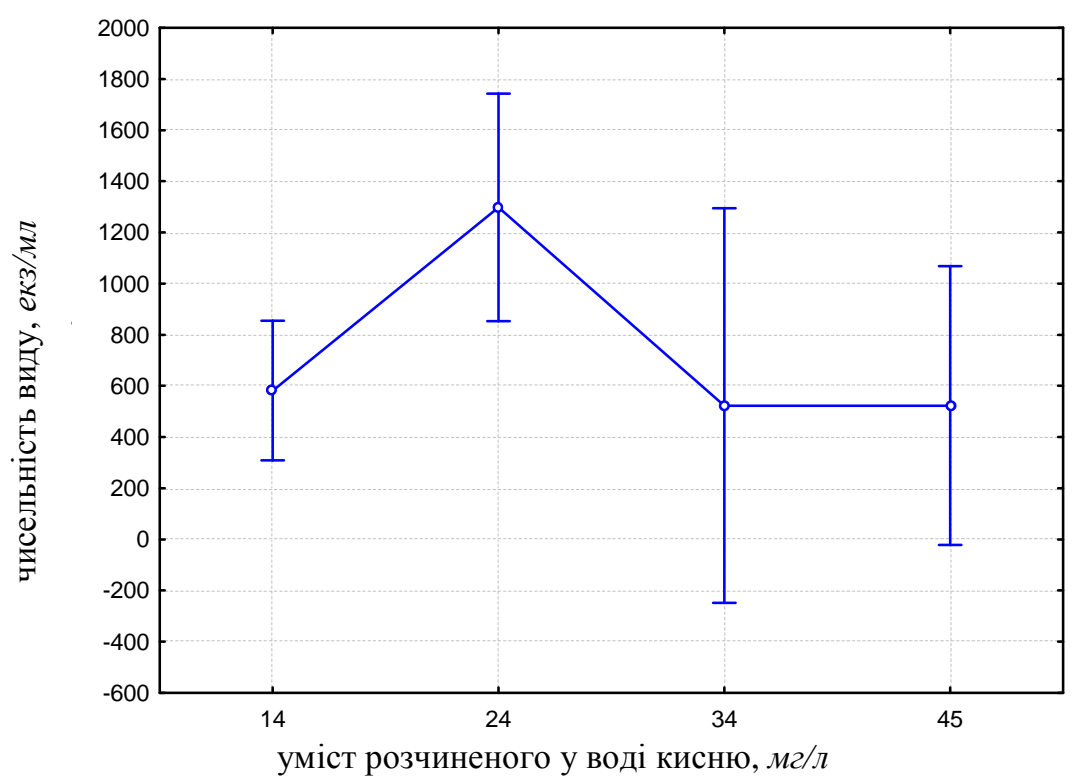

Рис. 8. Залежність чисельності B. saltans від умісту розчинених у воді органічних речовин (результати однофакторного дисперсійного аналізу)

Для виду B. saltans максимальні показники чисельності (988-1453) екз/мл простежуємо при $14,8-24,8$ мг $\mathrm{O}_{2} /$ л $(\mathrm{p}=0,05)$.

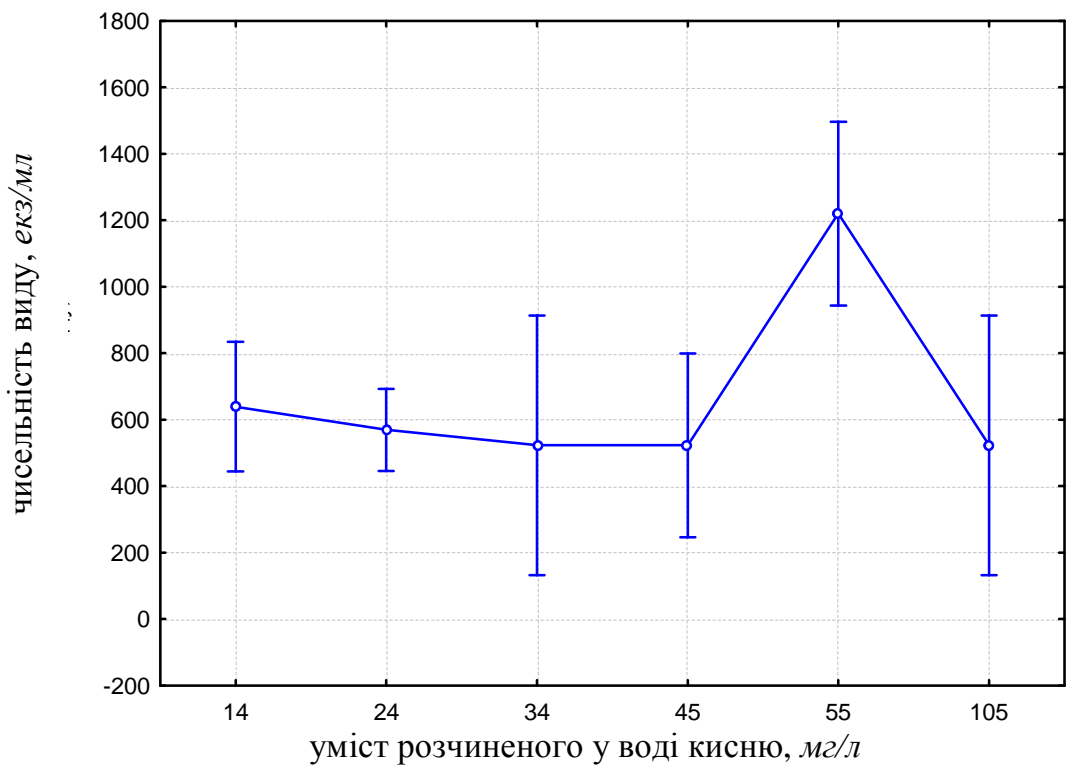

Рис. 9. Залежність чисельності P. nitrophilus від вмісту розчинених у воді органічних речовин (результати однофакторного дисперсійного аналізу)

Для P. nitrophilus оптимальний діапазон умісту розчинених органічних речовин становив 35,0 105,6 мг $\mathrm{O}_{2} /$ л $(\mathrm{p}=0,01)$. Найвищий показник чисельності (988-1453 екз/мл) зареєстровано при 45,155,1 мг $\mathrm{O}_{2} / л$. 


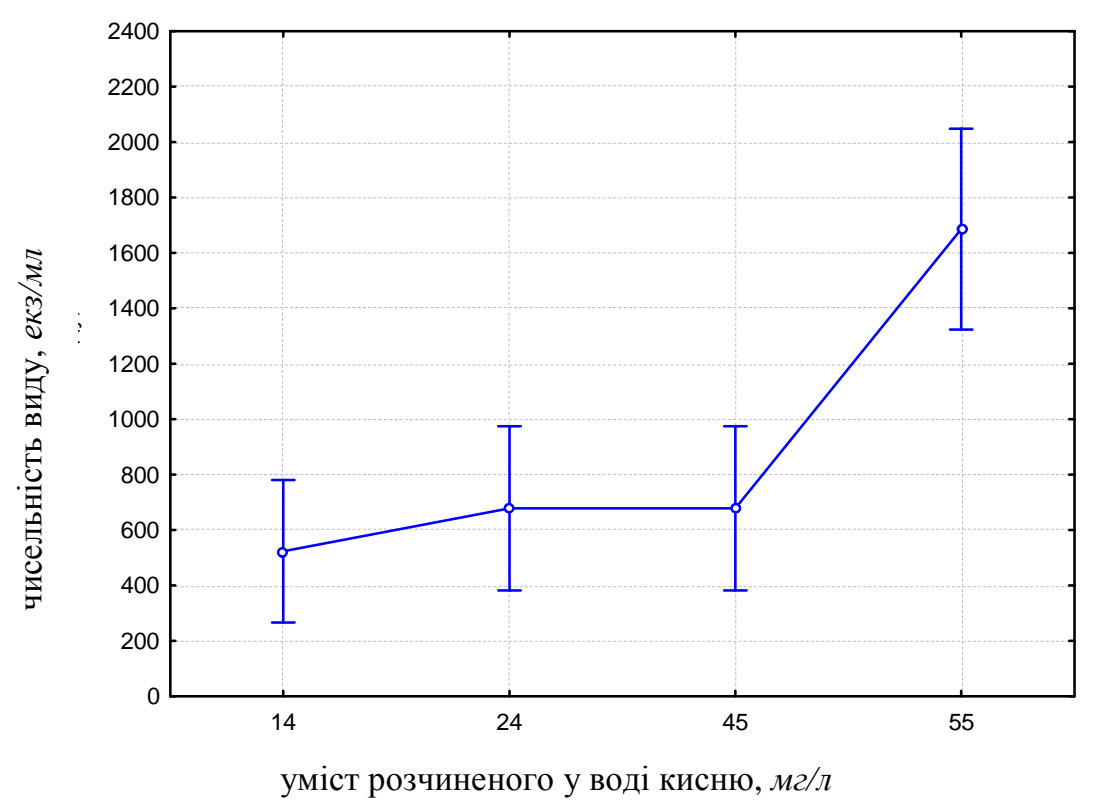

Рис. 10. Залежсність чисельності P. simplex від умісту розчинених у воді органічних речовин (результати однофакторного дисперсійного аналізу)

P. simplex характеризується максимальною чисельністю (988-1453 екз/мл) при такій же перманганатній окиснювальності, як і P. nitrophilus, тобто 45,1-55,1 мг $\mathrm{O}_{2} /$ л.

Отже, у результаті проведеного дослідження виявлено п'ять видів гетеротрофних джгутикових, чисельність яких залежала від концентрації розчиненого у воді кисню. При цьому для двох видів $A$. tachyploon та B. globosus, найвищі значення чисельності простежено при низьких концентраціях розчиненого кисню у воді, а для G. truncata, P. apiculatus i $R$. nasuta сплески чисельності зафіксовано при високих концентраціях кисню. Чотири види, максимум яких залежав від концентрації органічних речовин, й один вид - від активної реакції водного середовища.

\section{Джерела та література}

1. Золотарев В. А. Индикаторные сообщества микроперифитона разнотипных закисленних озер / В. А. Золотарев, Б. Ф. Жуков // Структура и функционирование экосистем ацидных озер. - СПб. : Наука. -1994. - С. 144-149

2. Жуков Б. Ф. К биологии пресноводных зоофлагеллат / Б. Ф. Жуков // Антропогенные факторы в жизни водоемов. - СПб. : Наука, 1976. - С 139-148.

3. Жуков Б. Ф. Атлас пресноводных гетеротрофных жгутиконосцев (биология, экология и систематика) / Б. Ф. Жуков. - Рыбинск : Ин-т биологии внутр. вод РАН, 1993. - 160 с.

4. Мыльников А. П. Биология бесцветных жгутиконосцев полисапробных зон : автореф. дис. ... канд. биол. наук : спец. 03.00 .18 «Гідробіологія» / А. П. Мыльников. - Борок, 1979. - 24. с.

5. Cairns J. Jr. The chemical environment of common freshwater protozoa / J. Jr. Cairns // Not. Nat. (Phila). 1964. - Vol. 365. - P. 1-16.

6. Fenchel T. The ecology of Protozoa / T. Fenchel. - Berlin : Madison/Springer-Verlag, 1987. - 197 p.

7. Kopylov A. I. Structure of planktonic microbial food web in a brackish stratified Siberian lake / A. I. Kopylov, D. B. Kosolapov, A. V. Romanenko, A. G. Degermendzhy // Aquatic Ecology. - 2002. - Vol. 36. - P. 179-204.

8. Vørs N. Heterotrophic amoebae, flagellates and Heliozoa from the Tvarminne Area, Gulf of Finland, in 19881990 / N. Vørs // Ophelia. - 1992. - Vol. 36, № 1. - P. 1-109.

Шевчук Светлана, Васильева Людмила. Зависимость численности гетеротрофных жгутиконосцев центральной части Украинского Полесья от абиотических факторов водной среды. Исследована зависимость численности гетеротрофных жгутиконосцев от абиотических факторов водной среды $(\mathrm{pH}$, содержание в воде растворенных кислорода и органических веществ). Зависимость определяли с помощью однофакторного дисперсионного анализа. Для видов Allantion tachyploon Sandon, 1924, Bodo globosus Stein, 1878, Goniomonas truncata (Fresenius) Stein, 1887, Phyllomitus apiculatus Skuja, 1948, Rhynchomonas nasuta (Stokes, 1888) Klebs, 1892 установлена достоверная связь между численнностю и содержанием растворенного в воде кислорода, для 
Ancyromonas sigmoides Kent, 1880, Bodo saltans Ehrenberg, 1832, Parabodo nitrophilus Skuja, 1948, Protaspis simplex Vǿrs, 1992 - между численностю и содержанием растворенных органических веществ. Кроме того, для Parabodo nitrophilus Skuja, 1948 также установлена достоверная связь между численностю и $\mathrm{pH}$.

Ключевые слова: гетеротрофные жгутиконосцы, Украинское Полесье, абиотические факторы водной среды.

Shevchuk Svitlana, Vasilieva Lyudmyla. Dependence of Heterotrophic Flagellates Central Part of Ukrainian Polissia Area Abundance on the Abiotic Factors Water Environment. We studied the dependence of heterotrophic flagellate numbers on the several hydrochemical parameters ( $\mathrm{pH}$, maintenance solubility in water oxygen and organic substances). This dependence was examined using one-way ANOVA. For species Allantion tachyploon Sandon, 1924, Bodo globosus Stein, 1878, Goniomonas truncata (Fresenius) Stein, 1887, Phyllomitus apiculatus Skuja, 1948 and Rhynchomonas nasuta (Stokes, 1888) Klebs, 1892 the reliable connection between the quantity and the maintenance solubility in water oxygen was determined, whereas in Ancyromonas sigmoides Kent, 1880, Bodo saltans Ehrenberg, 1832, Parabodo nitrophilus Skuja, 1948 and Protaspis simplex Vǿrs, 1992 the influence of maintenance solubility in water organic substances was significant. Furthermore in Parabodo nitrophilus Skuja, 1948 the $\mathrm{pH}$ value appreciably affect the species number.

Key words: heterotrophic flagellates, Ukrainian Polissia, abiotic factors water environment.

Стаття надійшла до редколегії 19.10.2015 p. 